\title{
Arbuscular Mycorrhizal and Dark Septate Endophyte Fungal Associations in South Indian Aquatic and Wetland Macrophytes
}

\author{
Kumar Seerangan ${ }^{1,2}$ and Muthukumar Thangavelu ${ }^{1}$ \\ ${ }^{1}$ Root and Soil Biology Laboratory, Department of Botany, Bharathiar University, Coimbatore, TamilNadu 641046, India \\ ${ }^{2}$ Institute of Plant and Microbial Biology, 128 Sec. 2, Academia Road, Nankang, Taipei 11529, Taiwan \\ Correspondence should be addressed to Muthukumar Thangavelu; tmkum@yahoo.com
}

Received 20 July 2014; Revised 18 October 2014; Accepted 20 October 2014; Published 24 November 2014

Academic Editor: Jutta Ludwig-Müller

Copyright (c) $2014 \mathrm{~K}$. Seerangan and M. Thangavelu. This is an open access article distributed under the Creative Commons Attribution License, which permits unrestricted use, distribution, and reproduction in any medium, provided the original work is properly cited.

\begin{abstract}
Investigations on the prevalence of arbuscular mycorrhizal (AM) and dark septate endophyte (DSE) fungal symbioses are limited for plants growing in tropical aquatic and wetland habitats compared to those growing on terrestrial moist or dry habitats. Therefore, we assessed the incidence of AM and DSE symbiosis in 8 hydrophytes and 50 wetland plants from four sites in south India. Of the 58 plant species examined, we found AM and DSE fungal symbiosis in 21 and five species, respectively. We reported for the first time AM and DSE fungal symbiosis in seven and five species, respectively. Intermediate-type AM morphology was common, and AM morphology is reported for the first time in 16 plant species. Both AM and DSE fungal colonization varied significantly across plant species and sites. Intact and identifiable AM fungal spores occurred in root zones of nine plant species, but AM fungal species richness was low. Though no clear relationship between AM and DSE fungal colonization was recognized, a significant negative correlation between AM colonization and spore numbers was established. Our study suggests that the occurrence of AM and DSE fungal symbiosis in plants growing in hydrophytic and wetland habitats is not as common as in terrestrial habitats.
\end{abstract}

\section{Introduction}

Most plants growing in their natural habitats are colonized by arbuscular mycorrhizal (AM) fungi belonging to the phylum Glomeromycota. The ability of AM fungi to establish a symbiotic association with a wide range of host plants renders these fungi to be an important component of most natural ecosystems [1]. These fungi aid plants in their uptake of nutrients and water from the substrates in exchange for carbon [1]. Nevertheless, plants growing in certain habitats like the aquatic and wetland habitats are either nonmycorrhizal or inconsistently mycorrhizal [2]. This arises from the fact that AM fungi are obligately aerobic, while many wetlands and aquatic habitats are frequently anoxic [3]. Therefore, it has been presumed that the presence and activity of AM fungi tend to decline as soil aeration level decreases [4]. Further, there is a general presumption that AM symbiosis may be less important for plants growing under submerged conditions as plants can absorb nutrients directly from their surroundings through the submerged parts. In spite of these, AM had been reported in plants growing in aquatic and wetland conditions [5-9]. In addition, results of studies examining the role of AM fungi in aquatic plants have shown that plants could benefit from mycorrhizal association. Such benefit could range from growth of an individual in a wetland community [10-12] to the wetland plant community as a whole [13]. In spite of these, information on the occurrence of AM in plants growing in aquatic and wetland habitats is limited compared to that of terrestrial habitats.

Based on the type and presence of AM fungal structures within plant roots, the colonization pattern has been termed as Arum-, Paris-, or intermediate-types [14]. In Arum-type, the fungal structures are mostly intercellular in contrast to Paris-type where the fungal structures are predominantly intracellular. The intermediate-type exhibits the characteristics of both Arum- and Paris-types [14]. Although many studies have reported the patterns of AM colonization in the roots of terrestrial plants, their occurrence in aquatic and wetland plants is largely unknown [15]. However, de Marins et al. [8] reported that the majority of the mycorrhizal plants 
they examined from a tropical river-floodplain system, Brazil, formed Paris-type AM.

The diversity of AM fungi in aquatic and wetland habitats is poorly understood like the functional roles of the fungi in these habitats. The presence of AM fungi has also been reported from several wetland ecosystems $[16,17]$. Nevertheless, many of these studies investigating the diversity of AM fungi in wet soils are based on the morphological characters of spores in rhizosphere soil, while a few have focused on the composition of AM fungi colonizing the roots of wetland plants $[18,19]$.

Recently, there has been an increasing awareness on another group of anamorphic ascomycetous fungi, which also frequently colonize roots of plants growing in various habitats. These fungi termed as dark septate endophyte (DSE) fungi produce dark septate or hyaline hyphae and microsclerotia. The DSE fungi often coexist with different types of mycorrhizal fungi, including the AM fungi. It is therefore essential to understand the interaction of these fungi as they inhabit the same niche within plant roots. The presence of DSE fungi in roots of aquatic and wetland plants has been reported $[8,20,21]$. Unlike AM fungi, the role of DSE fungi on host pant growth is not well resolved. Limited studies on the effect of DSE fungi on host growth suggest that DSE fungi could benefit plants like AM fungi under certain conditions (see [22] and references therein). However, the roles of AM and DSE colonization in plants of aquatic and wetland habitats are poorly understood. Therefore, the main aims of the present study were (i) to investigate the occurrence of AM and DSE fungal association in some aquatic and wetland plants, (ii) to evaluate the levels of colonization and colonization patterns, (iii) to assess the diversity of AM fungi associated with the aquatic habitats, and (iv) to investigate the existence of any possible relationship between AM and DSE fungal variables.

\section{Materials and Methods}

2.1. Study Sites. Samples were collected randomly from four different aquatic systems and sites at Tamilnadu, India. The first site (hereafter referred to as Site-A) was a river and adjoining area in Bhavani $\left(11^{\circ} 26^{\prime} 58.4^{\prime \prime} \mathrm{N}\right.$ and $77^{\circ} 41^{\prime} 23.8^{\prime \prime} \mathrm{E}$, $193 \mathrm{~m}$ a.s.l.). The average relative humidity ( $\mathrm{RH})$ of the area ranges from 65 to $87 \%$ and the average maximum and minimum temperatures vary from 26 to $33^{\circ} \mathrm{C}$ and 18 to $24^{\circ} \mathrm{C}$, respectively. The average rainfall of this site is $1116 \mathrm{~mm}$ per year. The second site (hereafter referred to as Site-B) was a pond located in Gobichettipalayam $\left(11^{\circ} 27^{\prime} 11.2^{\prime \prime} \mathrm{N}\right.$ and $77^{\circ} 30^{\prime} 52.9^{\prime \prime} \mathrm{E}, 213 \mathrm{~m}$ a.s.l.). The maximum and minimum temperatures range from 29 to $36^{\circ} \mathrm{C}$ and 19 to $24^{\circ} \mathrm{C}$, respectively. The rainfall within a year ranges from 6 to $164 \mathrm{~mm}$ with an annual average of $640 \mathrm{~mm}$. The third and fourth sites (here afterwards referred to as Site-C and Site-D) are a lake and river and adjoining area located at Perur $\left(10^{\circ} 58^{\prime} 09.8^{\prime \prime} \mathrm{N}\right.$ and $76^{\circ} 55^{\prime} 42.1^{\prime \prime} \mathrm{E}, 411.2 \mathrm{~m}$ a.s.l.) and Siruvani $\left(10^{\circ} 56^{\prime} 13.5^{\prime \prime} \mathrm{N}\right.$ and $76^{\circ} 41^{\prime} 14.1^{\prime \prime} \mathrm{N}, 1850 \mathrm{~m}$ a.s.l.), respectively. The maximum and minimum temperatures at Site-C vary from 29 to $34^{\circ} \mathrm{C}$ (average $31.6^{\circ} \mathrm{C}$ ) and 19 to $23^{\circ} \mathrm{C}$ (average $21.3^{\circ} \mathrm{C}$ ), respectively. The average rainfall within a year varies from 14 to $153 \mathrm{~mm}$, with an annual average of $693 \mathrm{~mm}$. The average RH for Site-C ranges from 56 to $90 \%$. The Site-D located in the Western Ghats region is characterized by average maximum and minimum temperatures of 25 and $16^{\circ} \mathrm{C}$, respectively. This site receives majority of its average $2800 \mathrm{~mm}$ annual rainfall from south-west monsoon (June to August) and to some extent from north-east monsoon (October to December).

2.2. Sample Collection. We collected root samples of 58 plant species belonging to 28 families including two ferns and soil/sediment samples of 55 plant species from the four different sites between December 2011 and February 2012. Maximum number of plant taxa was collected from Site-D (24 species) and minimum taxa was collected from Site-A (8 species) (Table 1). Eighty-eight percent of the sampled species were herbs (Table 2). The roots were positively identified as belonging to the intended plants and were carefully collected without damaging the cortex. The roots were washed free of adhering soil and debris and stored in FAA (formalin : glacial acetic acid :70\% ethyl alcohol 5:5:90, v:v:v) until processing. The soil/sediment sample collected from the individual plants of a species was shade dried and packed separately in polythene bags and stored until processing. One half of the soil sample was used for assessing the soil chemistry and the other half was used for the extraction and enumeration of AM fungal spores.

2.3. Determination of Soil Characters. Soil $\mathrm{pH}$ and electrical conductivity (EC) of the composite soil samples were determined in an aqueous solution of soil: water $(1: 1, \mathrm{v}: \mathrm{v})$ using digital meters. Total nitrogen $(\mathrm{N})$ and available phosphorous (P) were determined according to Jackson [23]. Exchangeable potassium $(\mathrm{K})$ was determined after extraction with ammonium acetate [23].

2.4. Processing and Quantification of Roots for AM and DSE Fungal Colonization. The fixed roots were washed free of the FAA, cut into $1 \mathrm{~cm}$ long bits, cleared $\left(90^{\circ} \mathrm{C}\right.$ for $60-90 \mathrm{~min}$.), and stained with trypan blue or chlorazol black $\mathrm{E}(0.05 \%$ in lactoglycerol) [24]. Flimsy roots were cleared by immersing in the clearing solution $(2.5 \% \mathrm{KOH})$ for $48-72$ hours. This minimized the loss of cortex due to heating. The stained roots were mounted onto slides and examined with an Olympus BX51 compound microscope $(\times 400)$ for the presence of AM and DSE fungal structures. The presence of aseptate hyphae, hyphal coils, arbuscules, or arbusculate coils with or without vesicles characterized AM fungal colonization. The DSE fungal colonization was characterized by regularly septate, melanized or hyaline hyphae with microsclerotia or moniliform cells. The percentage of root length colonization with AM and DSE fungi was estimated according to a magnified intersection method [25]. The classification of AM morphology was based on whether the fungal hyphae were present mainly as linear hyphae spreading inter- or intracellularly or within cells as coils according to the descriptions of Dickson [14].

2.5. Isolation, Enumeration, and Identification of AM Fungal Spores. Spores of AM fungi were retrieved from $100 \mathrm{~g}$ of 
TABLE 1: Soil characteristics and the number of plant taxa examined from different sites.

\begin{tabular}{|c|c|c|c|c|}
\hline \multirow[b]{2}{*}{ Characteristics } & \multicolumn{4}{|c|}{ Sites } \\
\hline & $\begin{array}{l}\text { Bhavani } \\
\text { (Site-A) }\end{array}$ & $\begin{array}{c}\text { Gobichettipalayam } \\
\text { (Site-B) }\end{array}$ & $\begin{array}{c}\text { Perur } \\
\text { (Site-C) }\end{array}$ & $\begin{array}{l}\text { Siruvani } \\
(\text { Site-D) }\end{array}$ \\
\hline Soil type & Sandy loam & Sandy clay loam & Sandy loam & Sandy loam \\
\hline $\mathrm{pH}$ & 7.12 & 6.90 & 8.17 & 6.80 \\
\hline Electrical conductivity $\left(\mathrm{dSm}^{-1}\right)$ & 0.09 & 0.09 & 0.08 & 0.08 \\
\hline Total nitrogen $\left(\mathrm{mg} \mathrm{kg}^{-1}\right)$ & 10.4 & 10.2 & 9.5 & 9.8 \\
\hline Available phosphorus $\left(\mathrm{mg} \mathrm{kg}^{-1}\right)$ & 9.5 & 10.0 & 4.8 & 9.7 \\
\hline Exchangeable potassium $\left(\mathrm{mg} \mathrm{kg}^{-1}\right)$ & 16.5 & 17.0 & 21.8 & 19.4 \\
\hline Number of plant taxa sampled & 8 & 9 & 19 & 25 \\
\hline
\end{tabular}

air-dried soil/sediment sample by wet-sieving and decanting technique and enumerated [26]. All intact AM fungal spores were counted. Spores were considered as intact when they were noncollapsed, with cytoplasmic content and free from any parasitic attack. These spores were transferred onto slides containing polyvinyl alcohol-lactoglycerol with or without Melzer's reagent for identification [27]. Identification of spores was based on spore morphology and subcellular characters using Olympus BX51 light microscope and by comparing to original descriptions (http://www.lrz-muenchen.de/ schuessler/amphylo/amphlo_ species.html). Spore morphology was also compared to the culture database established by INVAM (http://invam.wvu. $\mathrm{edu} /)$.

2.6. Statistical Analysis. Data of AM and DSE colonization were subjected to analysis of variance (ANOVA) to assess the variation between plant species among sites. Pearson's correlation was used to assess the relationship between AM and DSE variables. As values for root colonization and spore numbers generally follow a binomial distribution, the values were arcsine and log transformed, respectively, to achieve normalization prior to statistical analysis.

\section{Results}

3.1. Soil Characteristics of Study Sites. Soil/sediment $\mathrm{pH}$ was slightly acidic in Sites-B ( $\mathrm{pH}$ 6.9) and $-\mathrm{D}(\mathrm{pH}$ 6.8) and alkaline at Sites-A (7.12) and -C (pH 8.17) (Table 1). The EC ranged between 0.08 and 0.09 at all the four sites. Total $N$ ranged from $9.5 \mathrm{mg} \mathrm{kg}^{-1}$ (Site-C) to $10.4 \mathrm{mg} \mathrm{kg}^{-1}$ (Site-A) and available $P$ ranged between $4.8 \mathrm{mg} \mathrm{kg}^{-1}$ (Site-C) and $10 \mathrm{mg}$ $\mathrm{kg}^{-1}$ (Site-B). The exchangeable $K$ ranged between $17 \mathrm{mg} \mathrm{kg}^{-1}$ (Site-B) and $21.8 \mathrm{mg} \mathrm{kg}^{-1}$ (Site-C).

3.2. Occurrence of $A M$ and DSE Fungal Association. In the present investigation 8 hydrophytes and 50 wetland plant taxa (belonging to 28 families, including two pteridophytes) were assessed for AM and DSE fungal association. Of the six hydrophytes examined Nymphoides hydrophylla (Menyanthaceae) was mycorrhizal. Arbuscular mycorrhizal association was found in 20 wetland species. All members of the presumed nonmycorrhizal families like Amaranthaceae, Eriocaulaceae, and Polygonaceae lacked
AM fungal colonization. Similarly, members of certain families like Acanthaceae, Araceae, Asclepiadaceae, Convolvulaceae, Nymphaeaceae, Marsileaceae, Nelumbonaceae, Onagraceae, Piperaceae, Pontederiaceae, Rubiaceae, and Typhaceae reported to be mycorrhizal also lacked AM fungal colonization. The fungal entry into roots was characterized by the formation of an appressorium originating from the extraradical hyphae on the root surface (Figure 1(a)). The spread of the linear hyphae was either inter- or intra-cellular. Intracellular hyphal coils/arbusculate coils were present in roots of all the mycorrhizal plant species (Figures $1(\mathrm{~b})-1(\mathrm{~d})$ ). In contrast, vesicles were present only in $71 \%$ of the mycorrhizal species and were either inter- or intra-cellular.

The DSE fungal colonization was characterized by the presence of hyaline or darkly pigmented, regularly septate hyphae with or without microsclerotia or moniliform cells (Figures 1(e)-1(h)). Only 9\% of the plant species examined had DSE fungal association. All the DSE fungal colonized plants except Marsilea polycarpa (Marsileaceae) were also colonized by AM fungi. As DSE fungal hyphae were observed in all the colonized plant species, microsclerotia or moniliform cells were absent in F. falcata and S. nodiflora.

3.3. Extent of AM Fungal Colonization. The percentage root length with total AM colonization (\%RLTC) significantly varied with species $\left(F_{20,84}=28.615 ; P<0.001\right)$ and ranged from $49.19 \%$ (O. sativa) to $86.05 \%$ (L. parviflora). Similarly, percentage root length with hyphae (\%RLH) ranged from $18.41 \%$ (C. aestuans) to $54.86 \%$ (K. nemoralis). The variation in $\%$ RLH among plant species was significant $\left(F_{20,84}=\right.$ 250.084; $P<0.001)$. The percentage root length with vesicles (\% RLV) ranged from $4.36 \%$ (P. secundiflora) to $34.56 \%$ (C. iria $)$ and significantly varied among species $\left(F_{20,84}=432.557\right.$; $P<0.001)$. The percentage root length with arbusculate coils (\%RLAC) differed significantly among species $\left(F_{20,84}\right.$ $=176.167 ; P<0.001)$ and ranged from $11.40 \%$ (S. dulcis) to $38.83 \%$ (D. esculentum). Like \%RLH, the percentage root length with hyphal coils (\%RLHC) also varied significantly among species $\left(F_{20,84}=178.167 ; P<0.001\right)$ and ranged from $9.86 \%$ (O. sativa, P. secundiflora) to $32.23 \%$ (C. asiatica) (Table 3 ). The \%RLTC and percentage of root length with various AM fungal structures also differed significantly with sites (Table 4 ). The species $\times$ site interaction was also significant 
TABLE 2: Occurrence of arbuscular mycorrhizal (AM) and dark septate endophyte (DSE) fungal symbiosis and AM morphology in south Indian hydrophytes and wetland plant species.

\begin{tabular}{|c|c|c|c|c|c|}
\hline $\begin{array}{l}\text { Family } \\
\text { Plant name }\end{array}$ & Site $^{\mathrm{a}}$ & Habit form ${ }^{\mathrm{b}}$ & Life-forms ${ }^{c}$ & Mycorrhizal status $^{\mathrm{d}}$ & AM morphology \\
\hline \multicolumn{6}{|l|}{ Acanthaceae } \\
\hline Barleria cristata L. & III & $S$ & $\mathrm{~W}$ & - & - \\
\hline Hygrophila auriculata (Schumach.) Heine & III & $\mathrm{H}$ & $\mathrm{W}$ & - & - \\
\hline Justicia betonica $\mathrm{L}$. & IV & S & $\mathrm{W}$ & - & - \\
\hline \multicolumn{6}{|l|}{ Amaranthaceae } \\
\hline \multirow[t]{2}{*}{ Alternanthera sessilis (L.) R.Br. ex DC. } & IV & $\mathrm{H}$ & $\mathrm{W}$ & - & - \\
\hline & III & & $\mathrm{W}$ & - & - \\
\hline \multicolumn{6}{|l|}{ Apiaceae } \\
\hline Centella asiatica (L.) Urb. & IV & $\mathrm{H}$ & $\mathrm{W}$ & $\mathrm{AM}$ & I 4 \\
\hline \multicolumn{6}{|l|}{ Araceae } \\
\hline Colocasia esculenta (L.) Schott & III & $\mathrm{H}$ & $\mathrm{W}$ & - & - \\
\hline \multirow[t]{2}{*}{ Pistia stratiotes L. } & II & $\mathrm{H}$ & $\mathrm{F}$ & - & - \\
\hline & I & & $\mathrm{F}$ & - & - \\
\hline \multicolumn{6}{|l|}{ Asclepiadaceae } \\
\hline Asclepias curassavica L. & III & $\mathrm{H}$ & $\mathrm{W}$ & - & - \\
\hline \multicolumn{6}{|l|}{ Asteraceae } \\
\hline Ageratum conyzoides (L.) L. & IV & $\mathrm{H}$ & $\mathrm{W}$ & AM, DSE* & I 4 \\
\hline Eclipta prostrata (L.) L. & III & $\mathrm{H}$ & $\mathrm{W}$ & $\mathrm{AM}$ & I 4 \\
\hline Spilanthes calva Dc. & IV & $\mathrm{H}$ & $\mathrm{W}$ & $\mathrm{AM}^{*}$ & I $4^{*}$ \\
\hline Spilanthes uliginosa Sw. & IV & $\mathrm{H}$ & $\mathrm{W}$ & $\mathrm{AM}^{*}$ & I $4^{*}$ \\
\hline Synedrella nodiflora (L.) Gaertn. & III & $\mathrm{H}$ & $\mathrm{W}$ & AM, DSE* & I 4 \\
\hline \multicolumn{6}{|l|}{ Azollaceae } \\
\hline Azolla pinnata R. Br. & I & $S$ & $\mathrm{~F}$ & - & - \\
\hline \multicolumn{6}{|l|}{ Cannaceae } \\
\hline Canna indica L. & III & $\mathrm{H}$ & $\mathrm{W}$ & $\mathrm{AM}$ & I $4^{*}$ \\
\hline \multicolumn{6}{|l|}{ Commelinaceae } \\
\hline Commelina benghalensis L. & III & S & $\mathrm{W}$ & - & - \\
\hline Pollia secundiflora (Blume) Bakh.f. & IV & $\mathrm{H}$ & $\mathrm{W}$ & $\mathrm{AM}^{*}$ & I $4^{*}$ \\
\hline \multicolumn{6}{|l|}{ Convolvulaceae } \\
\hline Ipomoea aquatica Forssk. & III & S & $\mathrm{W}$ & - & - \\
\hline Ipomoea cairica (L.) Sweet & II & $\mathrm{H}$ & $\mathrm{W}$ & - & - \\
\hline Ipomoea eriocarpa $\mathrm{R} . \mathrm{Br}$. & I & S & $\mathrm{W}$ & - & - \\
\hline Merremia tridentata (L.) Hallier $\mathrm{f}$. & IV & $\mathrm{H}$ & $\mathrm{W}$ & - & - \\
\hline \multicolumn{6}{|l|}{ Cyperaceae } \\
\hline Cyperus articulatus $\mathrm{L}$. & I & $\mathrm{H}$ & $\mathrm{W}$ & - & - \\
\hline Cyperus cephalotes Vahl & IV & $\mathrm{H}$ & $\mathrm{W}$ & - & - \\
\hline Cyperus exaltatus Retz. & III & $\mathrm{H}$ & $\mathrm{W}$ & - & - \\
\hline Cyperus iria L. & IV & $\mathrm{H}$ & $\mathrm{W}$ & $\mathrm{AM}$ & I $4^{*}$ \\
\hline Cyperus pangorei Rottb. & III & $\mathrm{H}$ & $\mathrm{W}$ & - & - \\
\hline Fimbristylis argentea (Rottb.) Vahl & III & $\mathrm{H}$ & $\mathrm{W}$ & - & - \\
\hline Fimbristylis consanguinea Kunth & IV & $\mathrm{H}$ & $\mathrm{W}$ & - & - \\
\hline Fimbristylis falcata (Vahl) Kunth & II & $\mathrm{H}$ & $\mathrm{W}$ & AM, DSE* & I $3^{*}$ \\
\hline $\begin{array}{l}\text { Kyllinga nemoralis (J.R.Forst. \& G.Forst.) Dandy ex Hutch. \& } \\
\text { Dalziel }\end{array}$ & IV & $\mathrm{H}$ & $\mathrm{W}$ & $\mathrm{AM}$ & I $3^{*}$ \\
\hline \multicolumn{6}{|l|}{ Eriocaulaceae } \\
\hline Eriocaulon quinquangulare L. & III & $\mathrm{H}$ & $\mathrm{W}$ & - & - \\
\hline
\end{tabular}


TABLE 2: Continued.

\begin{tabular}{|c|c|c|c|c|c|}
\hline $\begin{array}{l}\text { Family } \\
\text { Plant name }\end{array}$ & Site $^{a}$ & Habit form ${ }^{\mathrm{b}}$ & Life-forms ${ }^{c}$ & Mycorrhizal status ${ }^{\mathrm{d}}$ & AM morphology ${ }^{e}$ \\
\hline \multicolumn{6}{|l|}{ Hydrocharitaceae } \\
\hline Hydrilla verticillata (L.f.) Royle & II & $\mathrm{H}$ & S & - & - \\
\hline Ottelia alismoides (L.) Pers. & IV & $\mathrm{H}$ & S & - & - \\
\hline \multicolumn{6}{|l|}{ Menyanthaceae } \\
\hline Nymphoides hydrophylla (Lour.) Kutze & III & $\mathrm{H}$ & $\mathrm{R}$ & $\mathrm{AM}$ & I $4^{*}$ \\
\hline \multicolumn{6}{|l|}{ Marsileaceae } \\
\hline Marsilea polycarpa Hook. \& Grev. & II & $\mathrm{H}$ & $\mathrm{W}$ & DSE* & - \\
\hline Marsilea minuta $\mathrm{L}$. & IV & $\mathrm{H}$ & $\mathrm{W}$ & - & - \\
\hline \multicolumn{6}{|l|}{ Nelumbonaceae } \\
\hline Nelumbo nucifera Gaertn. & I & $\mathrm{H}$ & $\mathrm{R}$ & - & - \\
\hline \multicolumn{6}{|l|}{ Nymphaeaceae } \\
\hline Nymphaea pubescens Willd. & III & $\mathrm{H}$ & $\mathrm{R}$ & - & - \\
\hline \multicolumn{6}{|l|}{ Onagraceae } \\
\hline Ludwigia perennis $\mathrm{L}$. & IV & $\mathrm{H}$ & $\mathrm{W}$ & - & - \\
\hline \multicolumn{6}{|l|}{ Piperaceae } \\
\hline Peperomia pellucida (L.) Kunth & III & $\mathrm{H}$ & $\mathrm{W}$ & - & - \\
\hline \multicolumn{6}{|l|}{ Poaceae } \\
\hline Axonopus compressus (Sw.) P.Beauv. & IV & $\mathrm{H}$ & $\mathrm{W}$ & $\mathrm{AM}^{*}$ & I $4^{*}$ \\
\hline Eragrostis gangetica (Roxb.) Steud. & II & $\mathrm{H}$ & $\mathrm{W}$ & - & - \\
\hline Jansenella griffithiana (C. Muell.) Bor & III & $\mathrm{H}$ & $\mathrm{W}$ & - & - \\
\hline Oryza sativa $\mathrm{L}$. & II & $\mathrm{H}$ & $\mathrm{W}$ & $\mathrm{AM}$ & I $4^{*}$ \\
\hline Sporobolus wallichii Munro ex Thwaites & III & $\mathrm{H}$ & $\mathrm{W}$ & $\mathrm{AM}^{*}$ & I $4^{*}$ \\
\hline \multicolumn{6}{|l|}{ Polygonaceae } \\
\hline Polygonum chinense $\mathrm{L}$. & IV & S & $\mathrm{W}$ & - & - \\
\hline Polygonum glabrum Willd. & I & $\mathrm{H}$ & $\mathrm{W}$ & - & - \\
\hline Polygonum hydropiper $\mathrm{L}$. & IV & $\mathrm{H}$ & $\mathrm{W}$ & - & - \\
\hline \multicolumn{6}{|l|}{ Pontederiaceae } \\
\hline Eichhornia crassipes (Mart.) Solms & I & $\mathrm{H}$ & $\mathrm{F}$ & - & - \\
\hline Monochoria vaginalis (Burm.f.) C. Presl. & II & $\mathrm{H}$ & $\mathrm{W}$ & - & - \\
\hline \multicolumn{6}{|l|}{ Rubiaceae } \\
\hline Hedyotis auricularia $\mathrm{L}$. & IV & $\mathrm{H}$ & $\mathrm{W}$ & - & - \\
\hline \multicolumn{6}{|l|}{ Scrophulariaceae } \\
\hline \multirow[t]{2}{*}{ Bacopa monnieri (L.) Wettst. } & IV & $\mathrm{H}$ & $\mathrm{W}$ & $\mathrm{AM}$ & $\mathrm{I} 4^{*}$ \\
\hline & I & & $\mathrm{W}$ & - & - \\
\hline Lindernia parviflora (Roxb.) Haines & IV & $\mathrm{H}$ & $\mathrm{W}$ & $\mathrm{AM}^{*}$ & $\mathrm{I} 4^{*}$ \\
\hline Scoparia dulcis L. & IV & $\mathrm{H}$ & $\mathrm{W}$ & $\mathrm{AM}$ & I 4 \\
\hline \multicolumn{6}{|l|}{ Tiliaceae } \\
\hline Corchorus aestuans L. & IV & $\mathrm{H}$ & $\mathrm{W}$ & $\mathrm{AM}^{*}$ & I $4^{*}$ \\
\hline \multicolumn{6}{|l|}{ Typhaceae } \\
\hline Typha angustata Bory \& Chaub. & II & $\mathrm{H}$ & $\mathrm{W}$ & - & - \\
\hline \multicolumn{6}{|l|}{ Verbenaceae } \\
\hline Lippia nodiflora Cham. & IV & $\mathrm{H}$ & $\mathrm{W}$ & $\mathrm{AM}$ & I $4^{*}$ \\
\hline \multicolumn{6}{|l|}{ Woodsiaceae } \\
\hline Diplazium esculentum (Retz.) Sw. & IV & $\mathrm{H}$ & $\mathrm{W}$ & AM, DSE* & $\mathrm{P}^{*}$ \\
\hline
\end{tabular}

${ }^{a}$ I: Site-A; II: Site-B; III: Site-C; IV: Site-D.

${ }^{\mathrm{b}} \mathrm{H}$ : herb; S: shrub.

${ }^{\mathrm{c}} \mathrm{W}$ : wetland; F: free floating; S: submerged; R: rooted emergent.

${ }^{\mathrm{d}}$ AM: arbuscular mycorrhizal; DSE: dark septate endophyte.

${ }^{\mathrm{e}} \mathrm{P}$ : Paris-type; I: intermediate-type AM.

${ }^{*}$ First report. 


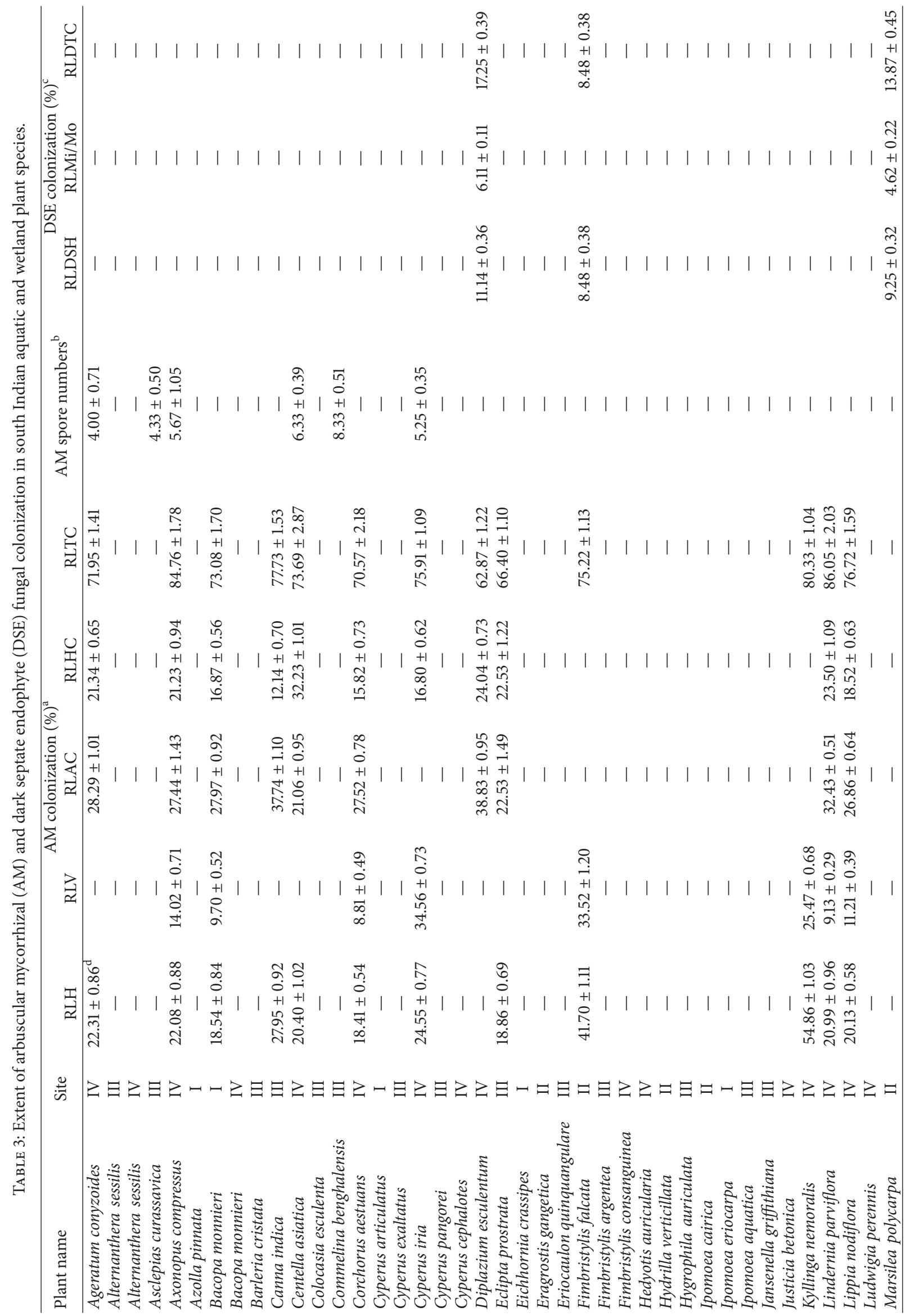




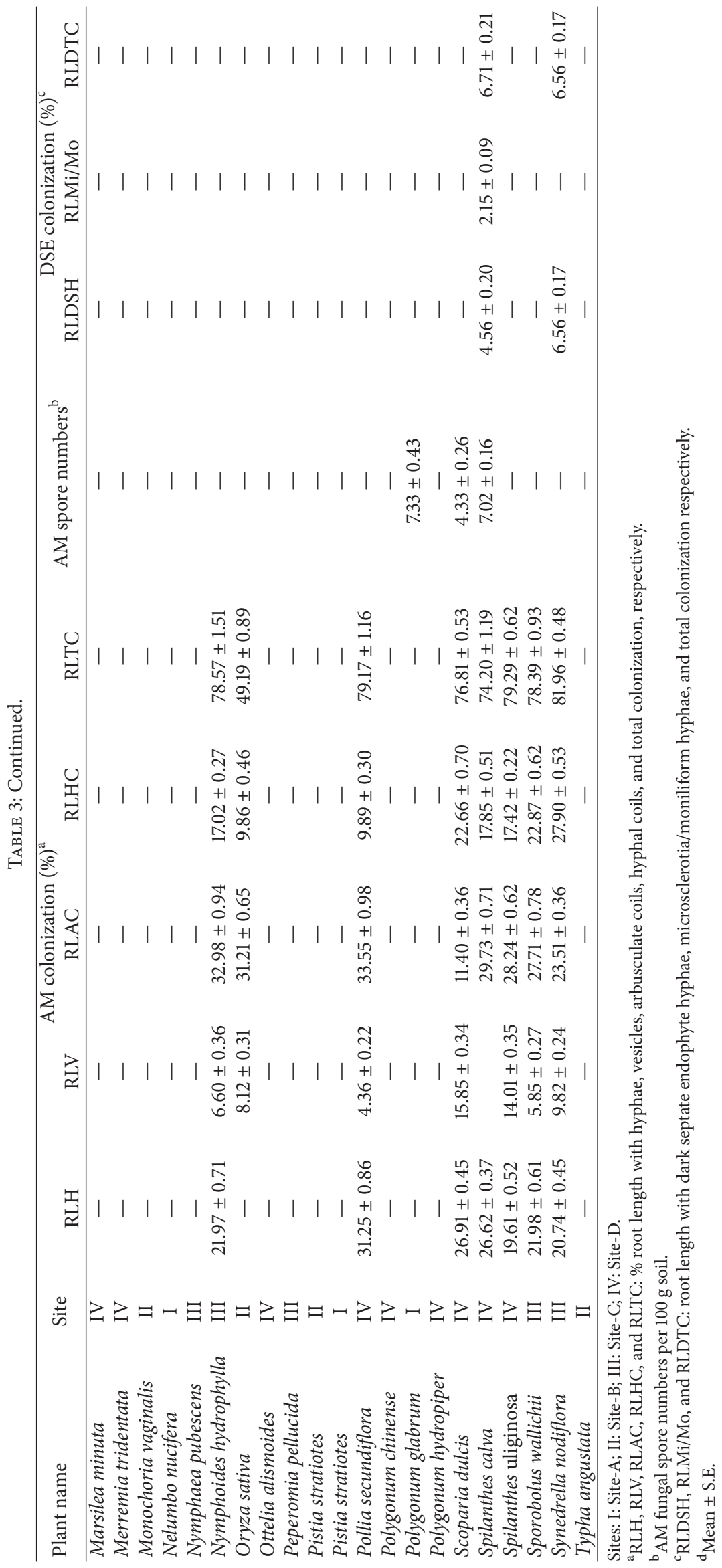




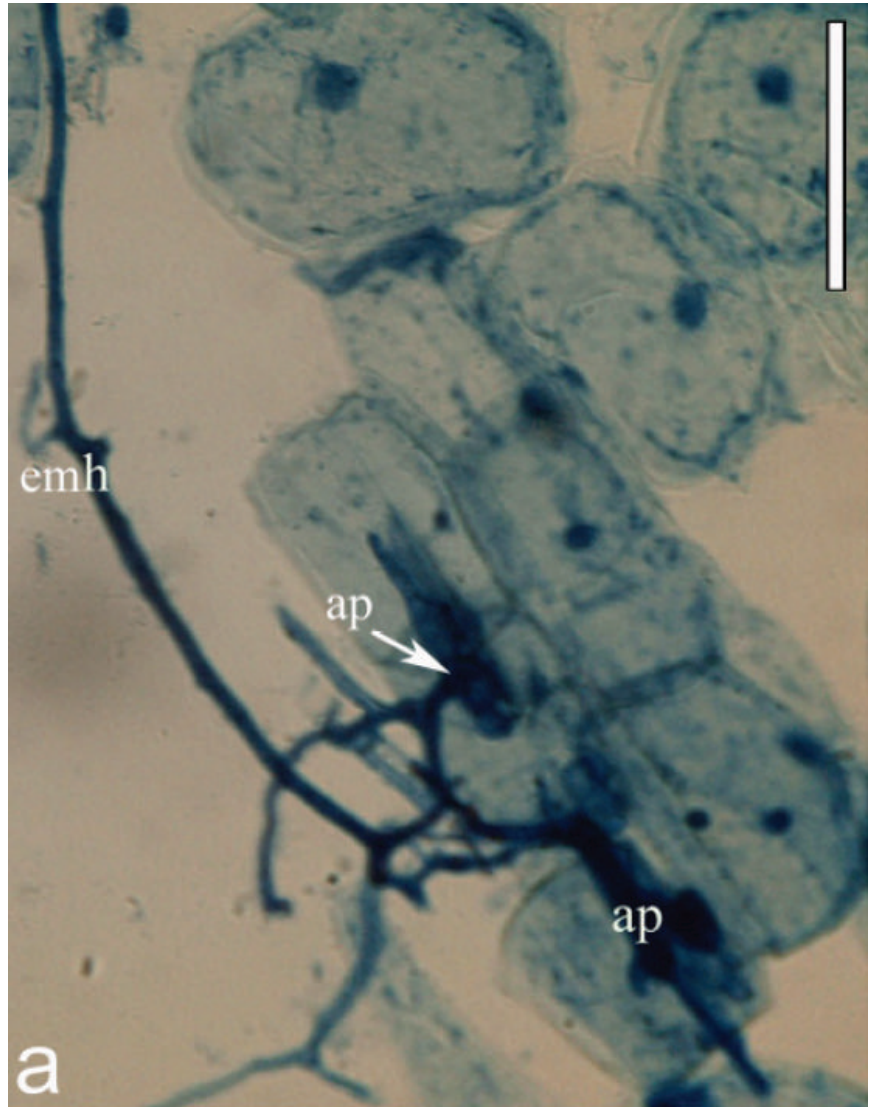

(a)

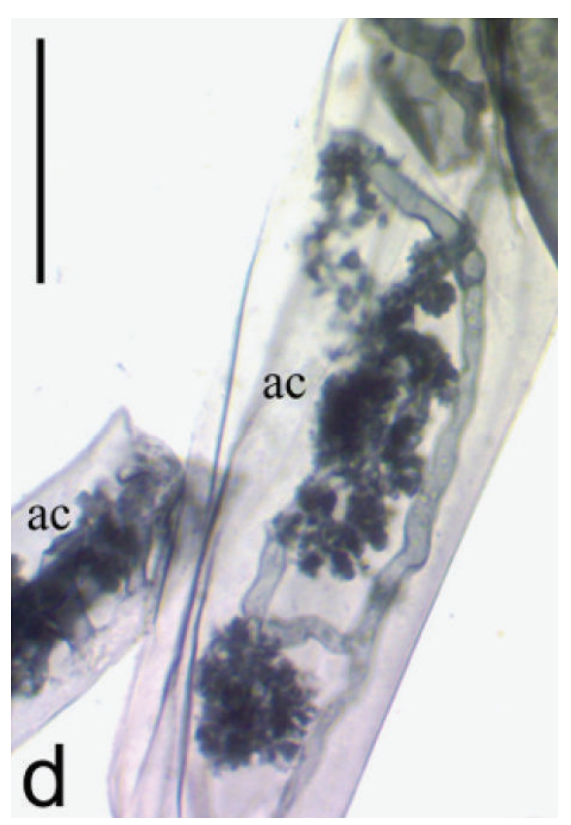

(d)

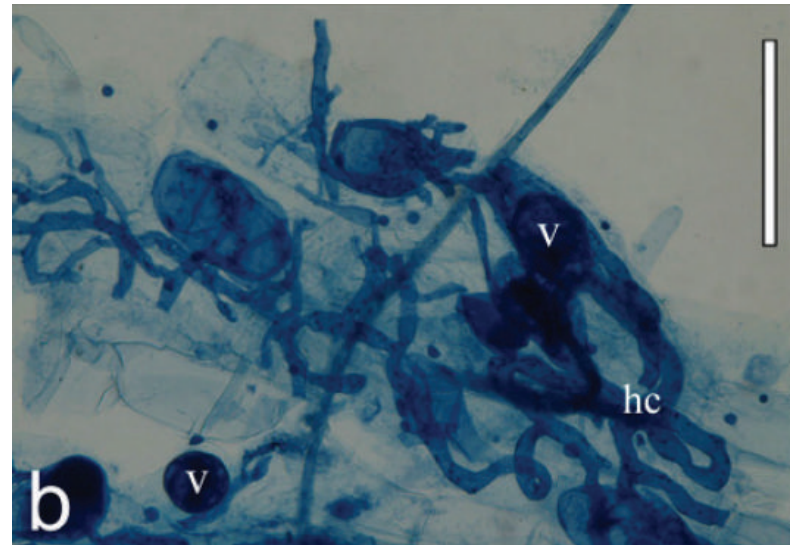

(b)

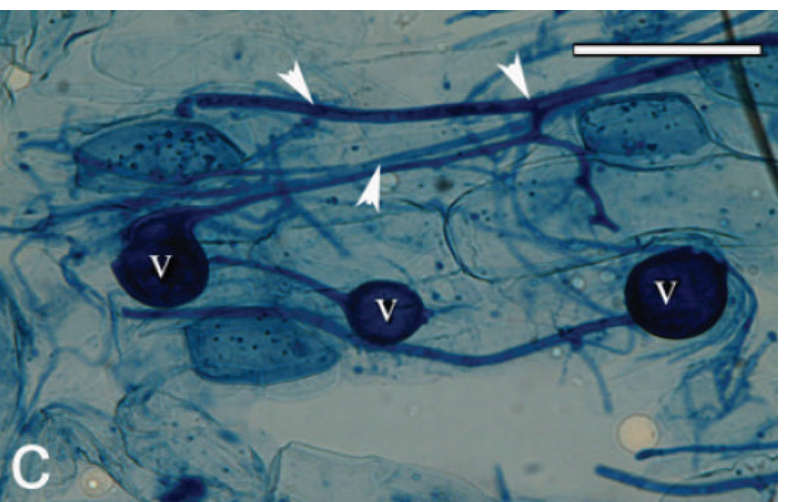

(c)

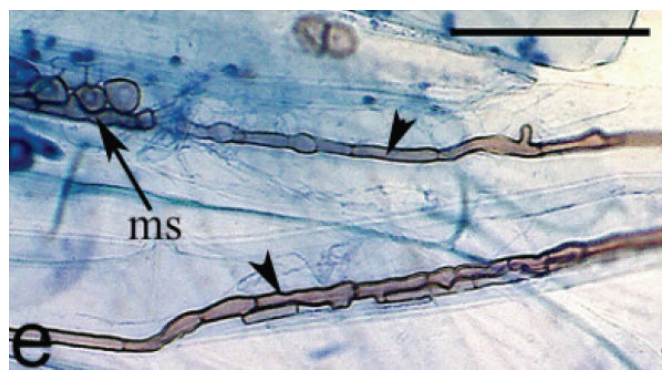

(e)

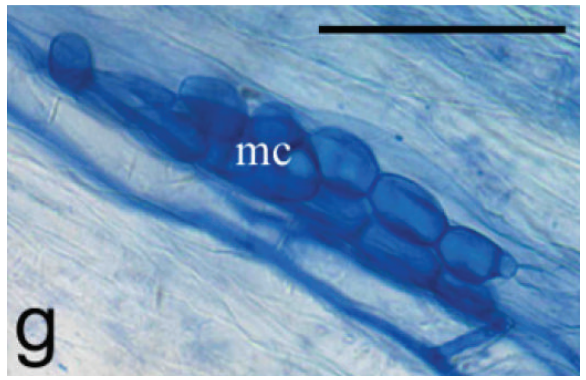

(g)

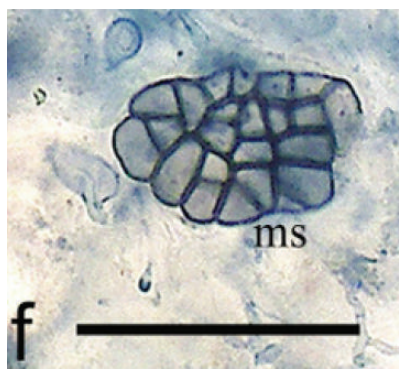

(f)

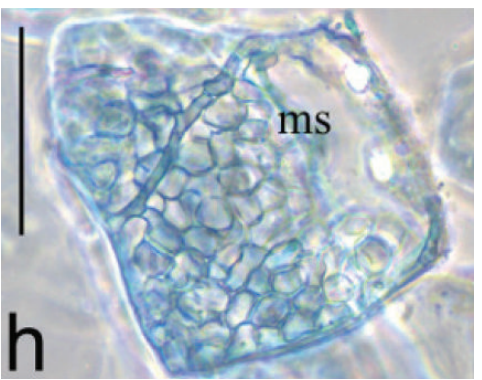

(h)

FIGURE 1: Arbuscular mycorrhizal (AM) (a-d) and dark septate endophyte (DSE) (e-h) fungal associations in aquatic and wetland plants. (a) Extramatrical hyphae (emh) and appressoria (ap) on root surface of Spilanthes clava, (b) Hyphal coils (hc) and vesicles (v) of AM fungi in Diplazium esculentum, (c) vesicles (v) and intercellular hyphae (white arrow heads) of AM fungi in Oryza sativa, (d) arbusculate coils (ac) of AM fungi in root cortical cells of D. esculentum, (e) septate DSE fungal hyphae (black arrow heads) and microsclerotia (ms) in Fimbristylis falcata, (f) microsclerotia (ms) in Marsilea polycarpa, (g) moniliform hyphae (mc) in Spilanthes clava, and (h) microsclerotia (ms) in D. esculentum. Scale bars $=50 \mu \mathrm{m}$. 
TABLE 4: $F$ values for the two-way analysis of variance for arbuscular mycorrhizal (AM) and dark septate endophyte (DSE) fungal colonization variables in south Indian aquatic and wetland plant species.

\begin{tabular}{|c|c|c|c|c|c|c|c|c|c|c|}
\hline \multirow{2}{*}{ Source } & \multicolumn{6}{|c|}{ AM fungal colonization ${ }^{\#}$} & \multicolumn{4}{|c|}{ DSE fungal colonization ${ }^{\# \#}$} \\
\hline & $\mathrm{df}$ & $\%$ RLH & $\% \mathrm{RLV}$ & $\%$ RLAC & \%RLHC & \%RLTC & df & $\%$ RLDSH & $\%$ RLMi/Mo & \%RLDTC \\
\hline Species & 13,84 & $293.32^{* * *}$ & $309.32^{* * *}$ & $181.64^{* * *}$ & $195.18^{* * *}$ & $13.71^{* * *}$ & 2,24 & $65.54^{* * *}$ & $373.42^{* * *}$ & $108.65^{* * *}$ \\
\hline Site & 3,84 & $55.86^{* * *}$ & $511.57^{* * *}$ & $174.712^{* * *}$ & $288.67^{* * *}$ & $60.32^{* * *}$ & 2,24 & $28.08^{* * *}$ & $102.06^{* * *}$ & $109.17^{* * *}$ \\
\hline Species $\times$ site & 4,84 & $284.51^{* * *}$ & $665.64^{* * *}$ & $169.11^{* * *}$ & $17.59^{* * *}$ & $49.38^{* * *}$ & 1,24 & $2.42^{*}$ & $981.89^{* * *}$ & $103.87^{* * *}$ \\
\hline
\end{tabular}

\#\%RLH, \%RLV, \%RLAC, \%RLHC, and \%RLTC: percentage root length with hyphae, vesicles, arbusculate coils, hyphal coils, and total colonization, respectively.

\#\#RLDSH, \%RLMi/Mo, and \%RLDTC: root length with dark septate endophyte hyphae, microsclerotia/moniliform hyphae, and total colonization, respectively.

*,*** Significant at $P<0.05$ and $P<0.001$, respectively.

for \%RLTC as well as root length with different AM fungal structures.

3.4. AM Fungal Morphology. Intermediate-type AM morphology was dominant in aquatic and wetland plant species examined in the present study. All the plants except D. esculentum had intermediate-type AM morphology. The intermediate subtype in most of the species was of intermediatetype 4 (I4) characterized by intercellular hyphae and intracellular hyphal/arbusculate coils. The AM morphology in D. esculentum was of typical Paris-type with intracellular hyphal/arbusculate coils (Figure 1(d)). Typical Arum-type AM morphology was not observed in any of the root samples examined. Arbuscules or arbusculate coils were absent in roots of sedges. However, roots of $C$. iria contained hyphal coils and the AM fungal hyphae in F. falcata and K. nemoralis were linear and both inter- and intra-cellular resembling intermediate-type 3 (I3).

3.5. AM Fungal Spore Numbers and Species. Spores of AM fungi were present in 9 of the 55 soil/sediment samples examined (Table 3). The soils of Asclepias curassavica (Asclepiadaceae), Commelina benghalensis (Commelinaceae), and Polygonum glabrum (Polygonaceae) contained spores of AM fungi in spite of the plants being nonmycorrhizal. Majority of the spores isolated were devoid of contents and were merely spore cases or were parasitized. The AM fungal spores were absent in the root zones of 15 mycorrhizal plant species. The number of AM fungal spores ranged from 4 spores per $100 \mathrm{~g}$ soil (A. conyzoides, A. curassavica, and S. dulcis) to 8 (C. benghalensis) spores per $100 \mathrm{~g}$ root zone soils (Table 2) and differed significantly among species $\left(F_{8,36}=7.67 ; P<0.001\right)$. Spore morphotypes belonging to five AM fungal species, such as Glomus macrocarpum Tul. \& Tul. Acaulospora laevis Gerd., Glomus ambisporum G.S Sm. \& N.C. Shenck, Glomus invermaium I. R. Hall., and an Acaulospora sp. were isolated from the rhizospheres of wetland plants. Spore numbers were significantly $(P<0.01)$ and negatively correlated to \%RLTC $(r=-0.527, n=24)$.

3.6. Extent of DSE Fungal Colonization. The percentage root length with DSE fungal colonization (\% RLDTC) varied significantly among species $\left(F_{5,24}=87.370 ; P<0.001\right)$ and ranged from $6.56 \%$ (S. nodiflora, S. calva) to $17.25 \%$ (D. esculentum) (Table 3$)$. The root length with dark septate fungal hyphae (\%RLDSH) ranged from $4.56 \%$ (S. calva) to $11.14 \%$ (D. esculentum) and differed significantly among species $\left(F_{5,24}=52.823 ; P<0.001\right)$. The root length with microsclerotia/moniliform cells (\%RLMi/Mo) exhibited significant variation among species $\left(F_{5,24}=354.461 ; P<0.001\right)$ and ranged from $2.15 \%$ (S. calva) to $6.11 \%$ (D. esculentum) (Table 3 ). The \%RLDSH, \%RLMi/Mo, and \%RLDTC varied with sites, and the species $\times$ site interactions for these variables were also significant (Table 4 ). The $\%$ RLDTC was not related to \%RLTC $(r=0.487, P>0.05, n=6)$.

\section{Discussion}

4.1. AM Fungal Association. The low incidence (36\%) of AM in the present study is in accordance with studies where low frequency in the occurrence of AM has been reported in plants from aquatic and wetland habitats $[6,8,28,29]$. This confirms the view that AM colonization is not common in plants of tropical aquatic and wetland habitats, unlike tropical terrestrial habitats [6]. To our knowledge AM is reported in seven plant species for the first time. The sparseness of $\mathrm{AM}$ in aquatic and wetland habitats is often attributed to the anoxic conditions of the flooded soils and sediments. Two reasons that contribute to the low biological activity in flooded soils are the low diffusion rate of oxygen in water and the rapid depletion of the oxygen in the inundated soil [30]. The incidence of AM was higher in wetland plants than in hydrophytes. This is in line with the findings of Khan $[31,32]$ who reported higher incidence of nonmycotrophy in aquatic plants than plants growing under wetland conditions. The higher prevalence of AM in plants of wetland than aquatic habitats could be attributed to the fact that plants in wetland soils could acquire colonization during dry seasons of the year. The rare occurrence of AM in aquatic and wetland plants can also be due to the direct effect of increasing soil moisture or flooding on AM fungal propagules. Germination of AM fungal spores as well as the number of fungal entry points in roots has been reported to be low in inundated soils with low oxygen concentrations and high redox potentials [33]. Nevertheless, spore germination tends to normalize with an increase in oxygen concentration [34].

Certain plant species (e.g., Barleria cristata, Colocasia esculenta, and Marsilea minuta) that were nonmycorrhizal in the present study were reported to be mycorrhizal from drier 
habitats $[35,36]$. This is similar to the observations of ŠrajKržič et al. [20] where plants that were normally mycorrhizal in terrestrial habitats were only occasionally or rarely mycorrhizal in intermittent aquatic habitats. The observations of the present study along with previous studies clearly indicate that even plant species that are fundamentally mycotrophic can be nonmycorrhizal in AM suppressive habitats as suggested by Brundrett [2]. Radhika and Rodrigues [7] also indicated that the AM symbiosis in aquatic and wetland habitats depended more on the habitat characteristics than on the plant species. In contrast, plants like C. iria and Fimbristylis falcata that were mycorrhizal in the present study were also reported so from drier soils $[37,38]$. This observation is in line with the findings of Bohrer et al. [39] where plant phenology was shown to significantly influence the occurrence of AM association in aquatic habitats compared to the abiotic factors. Nevertheless, B. monnieri in this study was mycorrhizal only at one of the two sites from which it was examined. Kyllinga nemoralis reported as nonmycorrhizal in dry soils [40] was mycorrhizal in the present study. These observations show that the factors contributing to the prevalence of AM symbiosis in aquatic and wetland habitats may be more complex than previously thought and could not be generalized.

Taxa in Araceae, Nymphaceae, Pontederiaceae, and Typhaceae were nonmycorrhizal similar to the observations of Khan and Belik [41], Kai and Zhiwei [6], and Beck-Nielsen and Madsen [5]. Members of these families generally have fine roots with abundant long root hairs and a well developed aerenchyma $[2,6]$. The highly efficient root system of these plants might enable them to exist and thrive independently of AM association. Nielsen et al. [42] presumed that an extensive development of aerenchyma could promote mycorrhization in aquatic plants. However, no demonstrable relationship was found between aerenchyma development and AM colonization level [20]. In contrast, Cornwell et al. [43] reported higher AM fungal colonization levels in aquatic plants with less aerenchyma. All the free-floating hydrophytes such as Azolla pinnata, Eichhornia crassipes, and Pistia stratiotes in the present study were nonmycorrhizal similar to the finding of earlier workers [5-8]. Absence of AM in free-floating hydrophytes is not surprising as roots of these plants may float freely in water throughout their existence without coming into contact with substrates containing AM fungal inocula. This minimizes the chance for the establishment of root colonization by AM fungi resulting in their nonmycotrophic condition. In contrast to these observations, Choudhury et al. [44] reported the presence of AM fungal hyphae and vesicles in roots of the free floating fern A. pinnata and Hussain et al. [45] reported typical AM association in E. crassipes examined from Pakistan.

We found AM only in three of the nine sedges examined confirming the fact that sedges occurring in wetlands are either nonmycorrhizal or rarely mycorrhizal $[2,35]$. The observation of AM fungal structures in the roots of a few sedges in the present study is in line with studies [21, 46] where sedges examined from wetlands were found to be colonized by AM fungi. Contrarily, Thormann et al. [47] failed to find any AM fungal structures in the roots of sedges they examined from Alberta bogs, fens, and marshes. Recently, Lagrange et al. [48] showed that the mycorrhizal status of sedges could be strongly influenced by habitat factors, especially the available $P$ concentration in the soil. These authors found that AM colonization of the sedge Costularia comosa was strongly restricted by the low levels of available $P$ in the native ultramafic soil. However, $P$ fertilization not only stimulated mycorrhization in C. comosa but also resulted in the establishment of a functional symbiosis [48]. A green house study has already established that even low levels of AM colonization could be functional and promote plant growth and nutrient uptake in sedges $[49,50]$. The low concentrations of available $P$ in the soil could not reason for the infrequent occurrence of $\mathrm{AM}$ in the present study since the available $P$ in the soils of the studied sites were higher (4.8 to $10.0 \mathrm{mg} / \mathrm{kg}$ of soil) than the $1.8 \mathrm{mg} / \mathrm{kg}$ of available $P$ reported by Lagrange et al. [48].

In our study, the rooted emergent aquatic $N$. hydrophylla was colonized by AM fungi. The presence of AM in emergent hydrophytes is often contradictory with studies reporting both presence and absence of AM symbiosis $[6,7,29,49,50]$. Previous studies have correlated the mycorrhizal status of emergent aquatics with nutrient and water gradient (e.g., [51-53]). These studies found reduced AM presence with increasing nutrient and water levels. Lagrange et al. [49] and White and Charvat [50] experimentally showed that the AM status of the emergent aquatic Lythrum salicaria was related to $P$ deficiency. Further, plant species of a habitat may depend differently on AM fungi as they vary in their nutrient requirements for optimum growth.

4.2. AM Morphology. The AM colonization patterns of aquatic and wetland plant species are not well resolved compared to plants growing in terrestrial and dry habitats [15]. To our knowledge AM morphology of 16 plant species has been reported for the first time. The majority of the plants possessing AM fungi had intermediate-type morphology similar to the observations of terrestrial habitats. This contradicts the observations of de Marins et al. [8] where seven of the nine mycorrhizal species in a tropical river-floodplain system from Brazil formed Paris-type AM. The fern, D. esculentum, had typical Paris-type AM similar to the observations by Muthukumar and Prabha [36]. An interesting observation noted in the present study was the absence of typical Arum-type AM in any of the mycorrhizal roots examined. This questions the general assumption that intercellular spaces are determinants of AM morphology [54], as development of aerenchyma is one of the several strategies that plants adopt to deal with hypoxic and anoxic conditions of soils saturated or flooded with water [55]. Although not examined in the present study, other studies have clearly shown that even plants from terrestrial habitats develop air spaces in their roots in response to increasing soil moisture or flooding $[6,55]$. The factors controlling AM morphology within roots are rather elusive and yet to be identified. In a classic study, Gerdemann [56] demonstrated the capability of an AM fungus to form different morphologies in varied hosts indicating the hosts influence on AM colonization patterns. In addition, Yamato [57] suggested that 
environmental factors such as light intensity and plant growth rate could influence AM fungal morphology within the roots. Studies have also shown that the AM morphology of a plant could vary with the fungus involved $[14,58,59]$. Therefore, in natural habitats where the chance for colonization of the root system by different AM fungi is high, the possibility for the formation of an intermediate type AM is rather higher than typical Arum- or Paris-type.

4.3. AM Colonization Levels. While AM fungal colonization levels may be reduced in inundated conditions, average colonization of mycorrhizal plants in the present study was relatively high (68\%), compared with average colonization levels reported for plants from aquatic and wetland habitats $[5,8,44,60]$. The average AM fungal colonization of the two sedges F. falcata and C. iria was also higher than those reported from upland habitats [37, 61]. Nevertheless, the average colonization levels are comparable to those of Dharmarajan et al. [28] and Weishampel and Bedford [21]. Limitations in the development of the extraradical phase of the fungi due to anoxic or hypoxic conditions of the soil/sediment might have restricted the proliferation of the fungi mostly to roots resulting in an intense colonization. The inhibition of the extraradical hyphal development is correlated with the changes in the redox potential of the sediments under inundated conditions. For example, BeckNielsen and Madsen [5] showed that the AM fungal hyphal density in the upper $4 \mathrm{~cm}$ of the lake sediments declined to one third from $6 \mathrm{~m}$ to $2 \mathrm{~m} \mathrm{~cm}^{-3}$ of sediment with a change of redox potential from $500 \mathrm{mV}$ to $150 \mathrm{mV}$.

4.4. AM Fungal Spore Numbers. Of the 55 plant species examined, intact and identifiable AM fungal spores were present only in the root zones of 9 species. This is in accordance with studies where AM fungal spores were reported to be absent or rare in the root zones of aquatic and wetland plant species $[8,28,62]$. The number of AM fungal spores in wetland soils has been positively related to redox potentials [63]. In contrast to the observations of de Marins et al. [8], majority of the AM spores isolated from the soil/sediment samples was deteriorated and was merely spore cases. The spore numbers of 4 to 8 per $100 \mathrm{~g}$ of soil are low compared to studies where a higher spore number has been reported from aquatic and wetland habitats (e.g., [44, 60]). A low AM fungal spore number has also been reported from the root zones of many of the aquatic macrophytes in a tropical river-floodplain system in Brazil [8]. One interesting aspect that was observed in the present study was the presence of AM fungal spores in the root zones A. curassavica, $C$. benghalensis, and $P$. glabrum which were nonmycorrhizal. Khan [31] and de Marins et al. [8] also observed the presence of AM fungal spores in the root zones of aquatic and wetland plants that were nonmycorrhizal. The spores in the root zones of nonmycorrhizal plants could be contributed by the coexisting plant species or spores could be washed in from the shores by water currents [8]. Harner et al. [64] recently showed that AM fungal propagules including spores could be dispersed by water currents and deposited in sediments. The observations of the present study support the suggestion
Clapp et al. [65] that spore population does not potentially reflect the level of AM colonization. Further, AM fungal spores were absent in the root zones of several mycorrhizal plant species in the present study. This clearly shows the involvement of AM fungal propagules other than spores in the process of mycorrhization in aquatic habitats. It has been well established that AM fungal structures like extraradical hyphae and mycorrhizal roots could act as propagules in initiating colonization [1]. Further, the negative correlation between AM fungal spore numbers and \%RLTC is similar to those observed in terrestrial ecosystems $[66,67]$ suggesting that the fungal variables respond differently to environmental conditions.

4.5. AM Fungal Spore Diversity. The species richness of AM fungi in the present study is similar to studies where a low diversity of AM fungi has been reported from the root zones of aquatic and wetland plants $[7,28]$. In contrast, several studies have recorded a species richness of 17-44 from the root zones of aquatic and wetland plants $[8,44,60,68]$. The one possible reason for the low AM fungal species richness in the present study may be the collection of the soils/sediments during the wrong season as sporulation has been shown to be seasonal for many AM fungi $[69,70]$.

4.6. DSE Fungal Occurrence and Colonization. In our study, only five of the 58 plant species (9\%) examined had DSE fungal association and are the first report of this symbiosis in all these species. This contrasts the observations where higher frequency of DSE fungal presence (70-100\%) has been reported in aquatic and wetland macrophytes $[8,20]$. The low incidence of DSE in the present study suggests that the anaerobic conditions of the studied habitat might also affect DSE fungal association similar to the AM symbiosis. In addition, most of the plants possessing DSE fungal colonization were also colonized by AM fungi. This corroborates the observations of other authors who also noted the cooccurrence of AM and DSE associations with plants of aquatic habitats $[8,20]$. However, the lack of relationship between these two fungal types indicates that these fungi do not influence each other within the root niche. The lack of interaction between these two fungal symbionts could be due to the different locations they occupy within the same root or different parts of the same root system [4]. The average \%RLDTC was $<10 \%$ of the roots possessing dual occurrence of AM and DSE fungi. This is similar to the observations where a low DSE fungal colonization has been reported in mycorrhizal test plants raised on aquatic sediments [19]. The results of the present study do not support the view that nonmycorrhizal plants have high frequency of DSE fungal association [71], as Marsilea polycarpa was the only nonmycorrhizal species to possess DSE association.

\section{Conclusion}

Our findings demonstrate that AM and DSE symbiosis in tropical aquatic and wetland plants are not as common as in tropical terrestrial habitats. The dominance of intermediatetype AM morphology in almost all the mycorrhizal plant 
species suggests that the intercellular spaces may not be a determining factor in AM morphological types. However, this needs further study. A low AM fungal spore number in spite of the high colonization level resembles those of forest ecosystems where AM fungi proliferate by propagules other than spores. Nevertheless, the use of metagenomics could shed more light on the AM fungal communities associated with plants growing in aquatic and wetland habitats. This could also lay foundation for future studies that can investigate the mechanism by which AM fungi survive and spread in the hypoxic and anoxic conditions. Further studies on the role of AM fungi on growth and nutrient uptake of plants in the aquatic and wetland conditions would throw more light on the significance of this symbiosis in these ecosystems. In addition, the low incidence of DSE symbiosis in the aquatic and wetland plants of the present study requires further investigation. This would enable us to understand the conditions that deter or inhibit the development of DSE symbiosis in saturated soils.

\section{Conflict of Interests}

The authors declare that there is no conflict of interests regarding the publication of this paper.

\section{References}

[1] S. E. Smith and D. J. Read, Mycorrhizal Symbiosis, Academic Press, San Diego, Calif, USA, 2008.

[2] M. Brundrett, "Mycorrhizal associations and other means of nutrition of vascular plants: understanding the global diversity of host plants by resolving conflicting information and developing reliable means of diagnosis," Plant and Soil, vol. 320, no. 1-2, pp. 37-77, 2009.

[3] P. Keddy, Wetland Ecology: Principles and Conservation, Cambridge University Press, New York, USA, 2000.

[4] C. Wagg, M. Pautler, H. B. Massicotte, and R. L. Peterson, “The co-occurrence of ectomycorrhizal, arbuscular mycorrhizal, and dark septate fungi in seedlings of four members of the Pinaceae," Mycorrhiza, vol. 18, no. 2, pp. 103-110, 2008.

[5] D. Beck-Nielsen and T. V. Madsen, "Occurrence of vesiculararbuscular mycorrhiza in aquatic macrophytes from lakes and streams," Aquatic Botany, vol. 71, no. 2, pp. 141-148, 2001.

[6] W. Kai and Z. Zhiwei, "Occurrence of arbuscular mycorrhizas and dark septate endophytes in hydrophytes from lakes and streams in southwest China," International Review of Hydrobiology, vol. 91, no. 1, pp. 29-37, 2006.

[7] K. P. Radhika and B. F. Rodrigues, "Arbuscular mycorrhizae in association with aquatic and marshy plant species in Goa, India," Aquatic Botany, vol. 86, no. 3, pp. 291-294, 2007.

[8] J. F. de Marins, R. Carrenho, and S. M. Thomaz, "Occurrence and coexistence of arbuscular mycorrhizal fungi and dark septate fungi in aquatic macrophytes in a tropical river-floodplain system," Aquatic Botany, vol. 91, no. 1, pp. 13-19, 2009.

[9] P. Kohout, Z. Sýkorová, M. Čtvrtlíková et al., "Surprising spectra of root-associated fungi in submerged aquatic plants," FEMS Microbiology Ecology, vol. 80, no. 1, pp. 216-235, 2012.

[10] S. P. Miller and R. R. Sharitz, "Manipulation of flooding and arbuscular mycorrhiza formation influences growth and nutrition of two semiaquatic grass species," Functional Ecology, vol. 14, no. 6, pp. 738-748, 2000.
[11] K. J. Stevens, S. W. Spender, and R. L. Peterson, "Phosphorus, arbuscular mycorrhizal fungi and performance of the wetland plant Lythrum salicaria L. under inundated conditions," Mycorrhiza, vol. 12, no. 6, pp. 277-283, 2002.

[12] R. M. Dunham, A. M. Ray, and R. S. Inouye, "Growth, physiology, and chemistry of mycorrhizal and nonmycorrhizal Typha latifolia seedlings," Wetlands, vol. 23, no. 4, pp. 890-896, 2003.

[13] B. E. Wolfe, P. A. Weishampel, and J. N. Klironomos, "Arbuscular mycorrhizal fungi and water table affect wetland plant community composition," Journal of Ecology, vol. 94, no. 5, pp. 905-914, 2006.

[14] S. Dickson, "The Arum-Paris continuum of mycorrhizal symbioses," New Phytologist, vol. 163, no. 1, pp. 187-200, 2004.

[15] S. Dickson, F. A. Smith, and S. E. Smith, "Structural differences in arbuscular mycorrhizal symbioses: more than 100 years after Gallaud, where next?” Mycorrhiza, vol. 17, no. 5, pp. 375-393, 2007.

[16] A. Sengupta and S. Chaudhuri, "Arbuscular mycorrhizal relations of mangrove plant community at the Ganges river estuary in India," Mycorrhiza, vol. 12, no. 4, pp. 169-174, 2002.

[17] Y. Wang, Q. Qiu, Z. Yang, Z. Hu, N. F.-Y. Tam, and G. Xin, "Arbuscular mycorrhizal fungi in two mangroves in South China," Plant and Soil, vol. 331, no. 1, pp. 181-191, 2010.

[18] J. Baar, I. Paradi, E. C. Lucassen et al., "Molecular analysis of AMF diversity in aquatic macrophytes: a comparison of oligotrophic and utra-oligotrophic lakes," Aquatic Botany, vol. 94, no. 2, pp. 53-61, 2011.

[19] R. Sudová, J. Rydlová, M. Čtvrtlíková, P. Havránek, and L. Adamec, "The incidence of arbuscular mycorrhiza in two submerged Isoëtes species," Aquatic Botany, vol. 94, no. 4, pp. 183-187, 2011.

[20] N. Šraj-Kržič, P. Pongrac, M. Klemenc, A. Kladnik, M. Regvar, and A. Gaberščik, "Mycorrhizal colonisation in plants from intermittent aquatic habitats," Aquatic Botany, vol. 85, no. 4, pp. 331-336, 2006.

[21] P. A. Weishampel and B. L. Bedford, "Wetland dicots and monocots differ in colonization by arbuscular mycorrhizal fungi and dark septate endophytes," Mycorrhiza, vol. 16, no. 7, pp. 495-502, 2006.

[22] K. K. Newsham, "A meta-analysis of plant responses to dark septate root endophytes," New Phytologist, vol. 190, no. 3, pp. 783-793, 2011.

[23] M. L. Jackson, Soil Chemical Analysis, Prentice-Hall, New Delhi, India, 1971.

[24] R. E. Koske and J. N. Gemma, "A modified procedure for staining roots to detect VA- mycorrhizas," Mycological Research, vol. 92, no. 4, pp. 486-488, 1989.

[25] T. P. McGonigle, M. H. Miller, D. G. Evans, G. L. Fairchild, and J. A. Swan, "A new method which gives an objective measure of colonization of roots by vesicular-arbuscular mycorrhizal fungi," New Phytologist, vol. 115, no. 3, pp. 495-501, 1990.

[26] T. Muthukumar and K. Udaiyan, "Arbuscular mycorrhizas of plants growing in the Western Ghats region, Southern India," Mycorrhiza, vol. 15, pp. 297-313, 2000.

[27] N. C. Schenck and Y. Perez, Manual for Identification of VA Mycorrhizal Fungi, INVAM, University of Florida, Gainesville, Fla, USA, 1990.

[28] S. Dharmarajan, K. Kannan, and C. Lakshminarasimhan, "Vesicular-arbuscular (VA) mycorrhizal status of some aquatic and marshy plants," Acta Botanica Indica, vol. 21, pp. 161-171, 1993. 
[29] R. Chaubal, G. D. Sharma, and R. R. Mishra, "Vesicular arbuscular mycorrhiza in subtropical aquatic and marshy plant communities," Proceedings of the Indian Academy of Sciences (Plant Sciences), vol. 91, no. 1, pp. 69-77, 1982.

[30] P. L. E. Bodelier, P. Frenzel, H. L. Darke et al., "Ecological aspects of microbes and microbial communities inhabiting the rhizosphere of wetland plants," Ecological Studies, vol. 190, pp. 205-238, 2006.

[31] A. G. Khan, "The occurrence of mycorrhizas in halophytes, hydrophytes and xerophytes, and of endogone spores in adjacent soils," Journal of General Microbiology, vol. 81, no. 1, pp. 7$14,1974$.

[32] A. G. Khan, "Occurrence of relationship between soil moisture gradient and pattern of VAM infection in Casuarina cunninghamiana growing in a transact on a creek embankment," in Proceedings of the International Symposium on Management of Mycorrhizas in Agriculture, Horticulture, and Forestry, The University of Western Australia, Perth, Australia, October 1992.

[33] C. P. P. Reid and G. D. Bowen, "Effects of soil moisture on V/A mycorrhiza formation and root development in Medicago," in The Soil-Root Interface, pp. 211-219, Academic Press, London, UK, 1979.

[34] F. LeTacon, F. A. Skinner, and B. Mosse, "Spore germination and hyphal growth of a vesicular-arbuscular mycorrhizal fungus Glomus mosseae (Gerdeman and Trappe) under reduced oxygen and increased carbon dioxide concentrations," Canadian Journal of Microbiology, vol. 29, pp. 1280-1285, 1983.

[35] B. Wang and Y. L. Qiu, "Phylogenetic distribution and evolution of mycorrhizas in land plants," Mycorrhiza, vol. 16, no. 5, pp. 299-363, 2006.

[36] T. Muthukumar and K. Prabha, "Arbuscular mycorrhizal and septate endophyte fungal associations in lycophytes and ferns of south India," Symbiosis, vol. 59, no. 1, pp. 15-33, 2013.

[37] T. Muthukumar and K. Udaiyan, "Seasonality of vesiculararbuscular mycorrhizae in sedges in a semi-arid tropical grassland," Acta Oecologica, vol. 23, no. 5, pp. 337-347, 2002.

[38] T. Muthukumar, K. Udaiyan, and P. Shanmughavel, "Mycorrhiza in sedges-an overview," Mycorrhiza, vol. 14, no. 2, pp. 6577, 2004.

[39] K. E. Bohrer, C. F. Friese, and J. P. Amon, "Seasonal dynamics of arbuscular mycorrhizal fungi in differing wetland habitats," Mycorrhiza, vol. 14, no. 5, pp. 329-337, 2004.

[40] S. Ragupathy and A. Mahadevan, "Distribution of vesiculararbuscular mycorrhizae in the plants and rhizosphere soils of the tropical plains, Tamil Nadu, India," Mycorrhiza, vol. 3, no. 3, pp. 123-136, 1993.

[41] A. G. Khan and M. Belik, "Occurrence and ecological significance of mycorrhizal symbiosis in aquatic plants," in Mycorrhiza: Structure, Function, Molecular Biology and Biotechnology, pp. 627-666, Springer, Heidelberg, Germany, 1995.

[42] K. B. Nielsen, R. Kjøller, P. A. Olsson, P. F. Schweiger, F. $\varnothing$. Andersen, and S. Rosendahl, "Colonisation and molecular diversity of arbuscular mycorrhizal fungi in the aquatic plants Littorella uniflora and Lobelia dortmanna in Southern Sweden," Mycological Research, vol. 108, no. 6, pp. 616-625, 2004.

[43] W. K. Cornwell, B. L. Bedford, and C. T. Chapin, "Occurrence of arbuscular mycorrhizal fungi in a phosphorus-poor wetland and mycorrhizal response to phosphorus fertilization," American Journal of Botany, vol. 88, no. 10, pp. 1824-1829, 2001.

[44] B. Choudhury, M. C. Kalita, and P. Azad, "Distribution of arbuscular mycorrhizal fungi in marshy and shoreline vegetation of
Deepar Beel Ramsar Site of Assam, India,' World Journal of Microbiology and Biotechnology, vol. 26, no. 11, pp. 1965-1971, 2010.

[45] R. Hussain, N. Ayub, J. Gul, A. Chaudhary, and A. G. Khan, "Incidence of vesicular-arbuscular mycorrhizal (VAM) fungi in aquaphytes growing in and around Rawalpindi/Islamabad," Pakistan Journal of Phytopathology, vol. 7, no. 2, pp. 98-103, 1995.

[46] S. D. Turner, J. P. Amon, R. M. Schneble, and C. F. Friese, "Mycorrhizal fungi associated with plants in ground-water fed wetlands," Wetlands, vol. 20, no. 1, pp. 200-204, 2000.

[47] M. N. Thormann, R. S. Currah, and S. E. Bayley, "The mycorrhizal status of the dominant vegetation along a peatland gradient in southern boreal Alberta, Canada," Wetlands, vol. 19, no. 2, pp. 438-450, 1999.

[48] A. Lagrange, L. L'Huillier, and H. Amir, "Mycorrhizal status of Cyperaceae from New Caledonian ultramafic soils: effects of phosphorus availability on arbuscular mycorrhizal colonization of Costularia comosa under field conditions," Mycorrhiza, vol. 23, no. 8, pp. 655-661, 2013.

[49] A. Lagrange, M. Ducousso, P. Jourand, C. Majorel, and H. Amir, "New insights into the mycorrhizal status of cyperaceae from ultramafic soils in New Caledonia," Canadian Journal of Microbiology, vol. 57, no. 1, pp. 21-28, 2011.

[50] J. A. White and I. Charvat, "The mycorrhizal status of an emergent aquatic, Lythrum salicaria L., at different levels of phosphorus availability," Mycorrhiza, vol. 9, no. 4, pp. 191-197, 1999.

[51] R. C. Anderson, A. E. Liberta, and L. A. Dickman, "Interaction of vascular plants and vesicular-arbuscular mycorrhizal fungi across a soil moisture-nutrient gradient," Oecologia, vol. 64, no. 1, pp. 111-117, 1984.

[52] S. D. Turner and C. F. Friese, "Plant-mycorrhizal community dynamics associated with a moisture gradient within a rehabilitated prairie fen," Restoration Ecology, vol. 6, no. 1, pp. 44-51, 1998.

[53] R. M. Miller, C. I. Smith, J. D. Jastrow, and J. D. Bever, "Mycorrhizal status of the genus Carex (Cyperaceae)," The American Journal of Botany, vol. 86, no. 4, pp. 547-553, 1999.

[54] M. Brundrett and B. Kendrick, "The roots and mycorrhizas of herbaceous woodland plants. II. Structural aspects of morphology," New Phytologist, vol. 114, no. 3, pp. 469-479, 1990.

[55] D. E. Evans, "Aerenchyma formation," New Phytologist, vol. 161, no. 1, pp. 35-49, 2004.

[56] J. W. Gerdemann, "Vesicular-arbuscular mycorrhizae formed on maize and tuliptree by Endogone fasciculate," Mycologia, vol. 57, pp. 562-575, 1965.

[57] M. Yamato, "Morphological types of arbuscular mycorrhizal fungi in roots of weeds on vacant land," Mycorrhiza, vol. 14, no. 2, pp. 127-131, 2004.

[58] T. R. Cavagnaro, L.-L. Gao, F. A. Smith, and S. E. Smith, "Morphology of arbuscular mycorrhizas is influenced by fungal identity," New Phytologist, vol. 151, no. 2, pp. 469-475, 2001.

[59] S. E. Smith, F. A. Smith, and I. Jakobsen, "Functional diversity in arbuscular mycorrhizal (AM) symbioses: the contribution of the mycorrhizal P uptake pathway is not correlated with mycorrhizal responses in growth or total P uptake," New Phytologist, vol. 162, no. 2, pp. 511-524, 2004.

[60] K. P. Radhika, J. D’souza, and B. F. Rodrigues, "Arbuscular mycorrhizae in aquatic plants, India," in Mycorrhiza: Occurrence in Natural and Restored Environments, pp. 265-274, Nova Science, New York, NY, USA, 2012. 
[61] T. Muthukumar, K. Udaiyan, and S. Manian, "Vesiculararbuscular mycorrhizae in tropical sedges of southern India," Biology and Fertility of Soils, vol. 22, no. 1-2, pp. 96-100, 1996.

[62] K. J. Stevens and R. L. Peterson, "The effect of a water gradient on the vesicular-arbuscular mycorrhizal status of Lythrum salicaria L. (purple loosestrife)," Mycorrhiza, vol. 6, no. 2, pp. 99-104, 1996.

[63] A. G. Khan, "Occurrence and importance of mycorrhizae in aquatic trees of New South Wales, Australia," Mycorrhiza, vol. 3, no. 1, pp. 31-38, 1993.

[64] M. J. Harner, N. Opitz, K. Geluso, K. Tockner, and M. C. Rillig, "Arbuscular mycorrhizal fungi on developing islands within a dynamic river floodplain: an investigation across successional gradients and soil depth," Aquatic Sciences, vol. 73, no. 1, pp. 3542, 2011.

[65] J. P. Clapp, J. P. Young, J. W. Merryweather, and A. H. Fitter, "Diversity of fungal symbionts in arbuscular mycorrhizas from a natural community," New Phytologist, vol. 130, no. 2, pp. 259265, 1995.

[66] K. Udaiyan, A. Karthikeyan, and T. Muthukumar, "Influence of edaphic and climatic factors on dynamics of root colonization and spore density of vesicular-arbuscular mycorrhizal fungi in Acacia farnesiana Willd. and A. planifrons W.et.A," Trees: Structure and Function, vol. 11, no. 2, pp. 65-71, 1996.

[67] A. Hindumathi and B. N. Reddy, "Occurrence and distribution of arbuscular mycorrhizal and microbial flora in the rhizosphere soils of mungbean (Vigna radiata (L.) Wilczek) and soybean (Glycine max (L.) Merr .) from Adilabad, Nizamabad and Karimnagar districts of Andhra Pradesh state, India," Advances in Biosciences and Biotechnology, vol. 2, pp. 275-286, 2011.

[68] T. Kumar and M. Ghose, "Status of arbuscular mycorrhizal fungi (AMF) in the Sundarbans of India in relation to tidal inundation and chemical properties of soil," Wetlands Ecology and Management, vol. 16, no. 6, pp. 471-483, 2008.

[69] R. Bajwa, A. Yaqoob, and A. Javaid, "Seasonal variation in VAM in wet land plants," Pakistan Journal of Biological Sciences, vol. 4, pp. 464-470, 2001.

[70] J. D'Souza and B. F. Rodrigues, "Seasonal diversity of arbuscular mycorrhizal fungi in mangroves of Goa, India," International Journal of Biodiversity, vol. 2013, Article ID 196527, 7 pages, 2013.

[71] J. R. Barrow and R. E. Aaltonen, "Evaluation of the internal colonization of Atriplex canescens (pursh) nutt. roots by dark septate fungi and the influence of host physiological activity," Mycorrhiza, vol. 11, no. 4, pp. 199-205, 2001. 

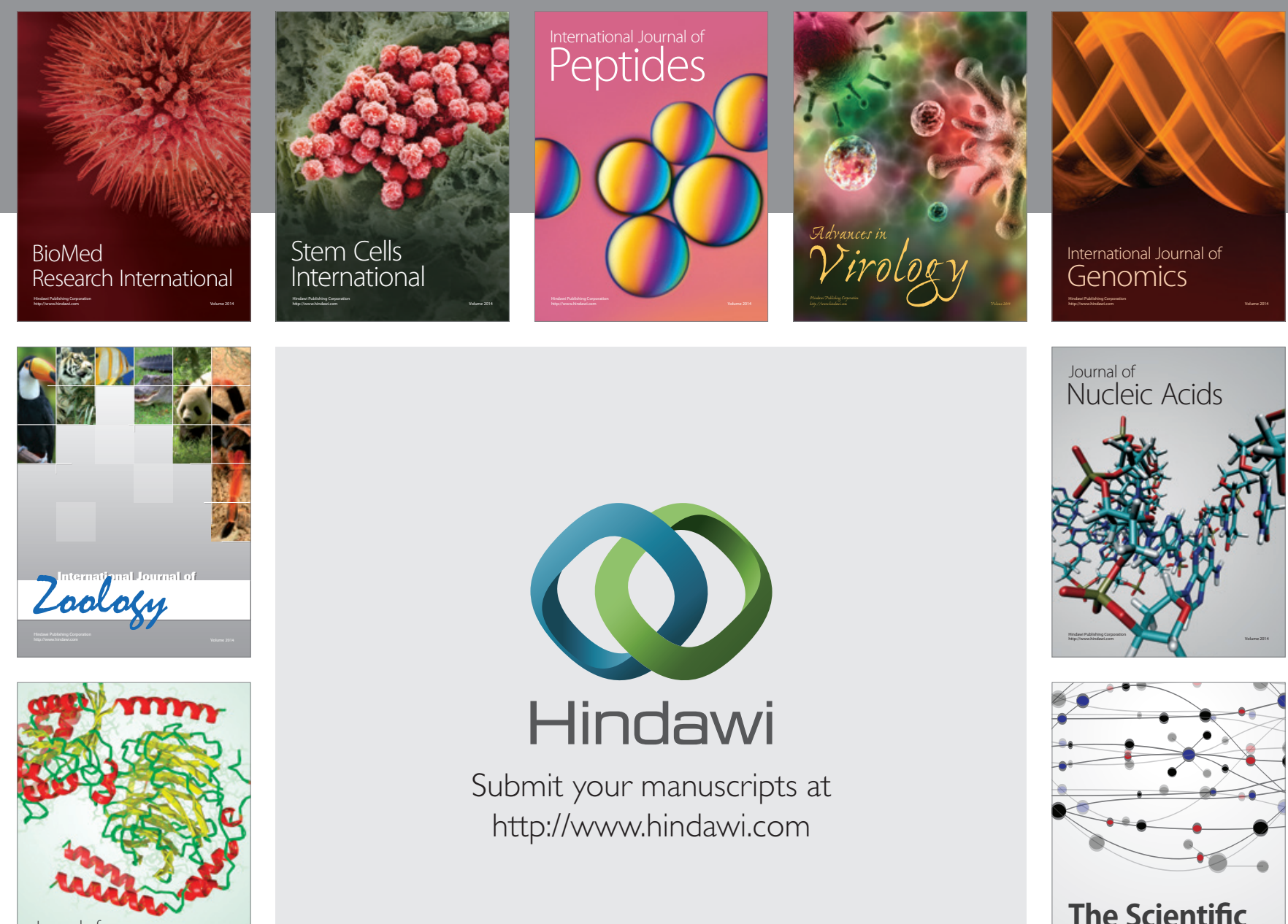

Submit your manuscripts at

http://www.hindawi.com

Journal of
Signal Transduction
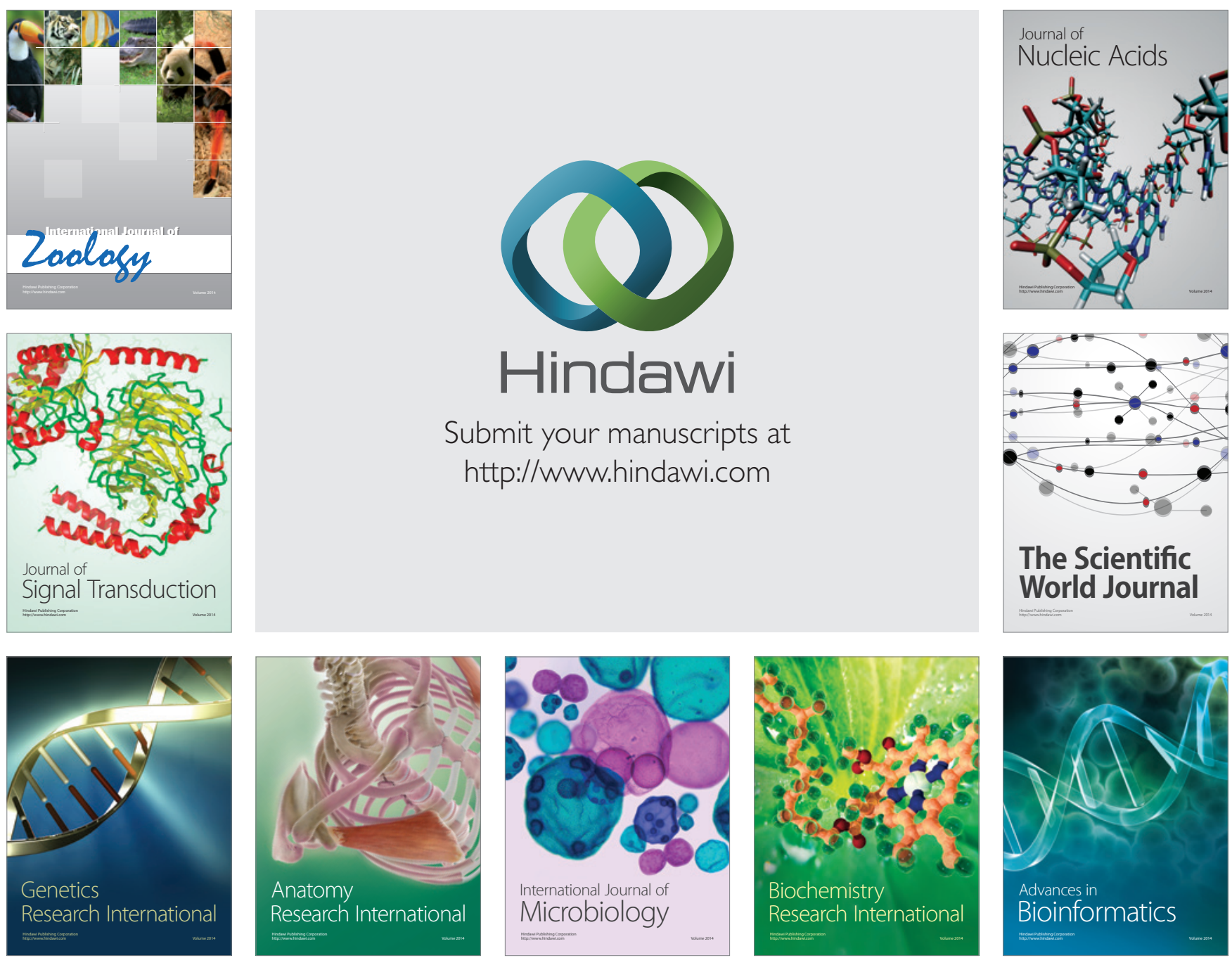

The Scientific World Journal
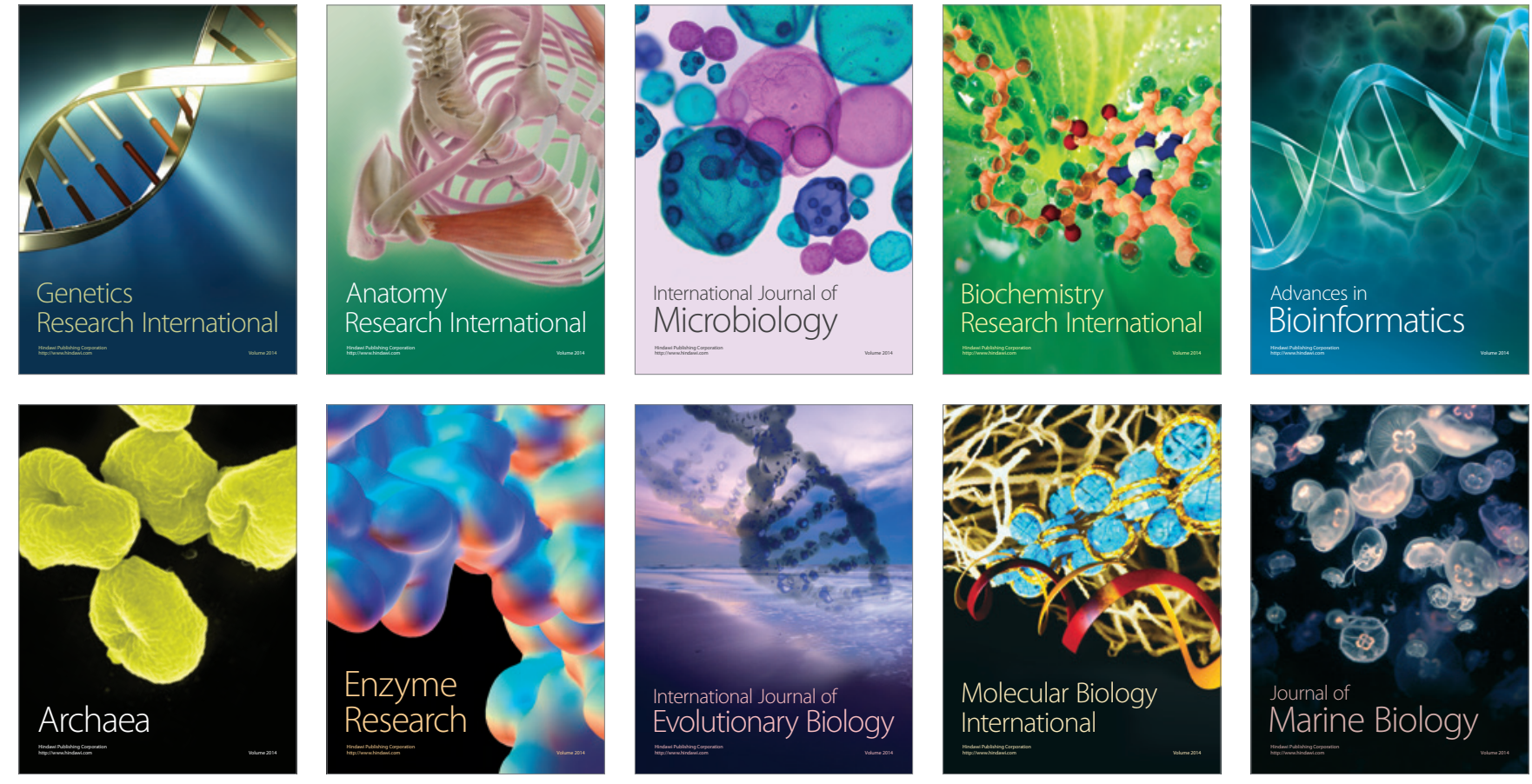